保健物理, 7, 225 227（1972）

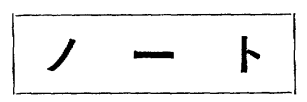

シリカゲルを用いた排気トリチウム量の計測

山本峯澄*1, 清木義弘*1, 水書利雄*1

(1972 年 8 月 15 日受理)

Measurement of Tritium in Exhausted Air Using Silicagel

Hozumu YAMAMOTO, *1 Yoshihiro SEIKI, *1 Toshio MIZUGAKI*1

\section{I 緒言}

排気空気中のトリチウム濃度は, 水蒸気凝集法によっ て測定していたが，この方法はドライアイスなと寒剤が 必要なこと, 連続捕集が困難なこと, 排気の温湿度を測 定しなければならないことなどの欠点があった。この欠 点を補ら方法として，排気中のトリチウムをシリカゲル に長期間にわたって吸着させ，吸着した水分を加熱して 脱着し, 脱着した水のトリチウム濃度を液体シンチレー ションカウンタで計測することによって，排気トリチウ ムの平均濃度と排出量を求める方法を試験した。

シリカダルを用いて空気中トリチウム濃度を計測する 方法は，これまでる報告されているが1 3)，ここでは長 期間サンプリングするらえでの吸着性能と, 測定試料水 中トリチウム濃度から, サンプリングトリチウム量を簡 便に求める方法について報告する。

\section{II シリカゲルの吸着性能}

温度 $20^{\circ} \mathrm{C}$ から $50^{\circ} \mathrm{C}$ K郝けるシリカゲルの水分吸着 性能の試験に用いた装置を Fig. 1 亿示す。トリチウえ を含む水溶液（約 $500 \mu \mathrm{Ci} / \mathrm{m} l$ ) をバブリングさせて， ト リチウムを含む空気（水蒸気分圧 $10.5 \mathrm{mmHg}$ )*2 を発生 させ，一定の温度に保たれた箱内のシリカゲル吸着塔に 流入させた。吸着塔の前後には電離箱 $(1.5 l)$ を設置し，

\footnotetext{
*1 日本原子力研究所保健物理安全管理部; 茨城県那珂郡東海 村 (千319-11)

Div of Health Physics and Safety, Japan Atomic Energy Research Institute; Tokai-mura, Naka-gun, Ibaraki-ken.

*2 $20^{\circ} \mathrm{C}$ における相対湿度 $60 \%$ 。
}

吸着塔前後のトリチウム濃度を測定して, シリカダルの 水蒸気透過率を求めた。また, 一定時間ごとに吸着塔の 重量を計測して, シリカゲルに吸着した水量を求めた。 試験したシリカゲルは, 和光純薬工業 K K 製 $5 \sim 20$ メッ シュ(中粒) で, 吸着塔に $370 \mathrm{~g}$ 充填して使用した。

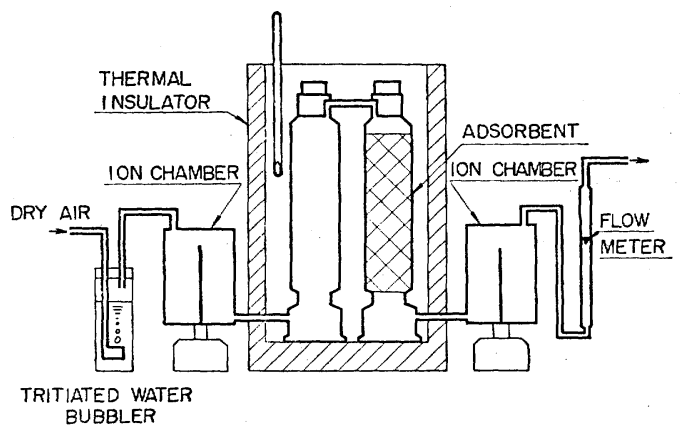

Fig. 1 Apparatus for measuring the penetration of water vapor through adsorbent.

吸着塔雾团気温度を $20^{\circ} \mathrm{C}, 30^{\circ} \mathrm{C}, 40^{\circ} \mathrm{C}, 50^{\circ} \mathrm{C}$ 維持 し,トリチウム含有空気を流量率 $6 \mathrm{l} / \mathrm{min}$ で流通させた ときの水蒸気透過率を求めた。Fig. 2 は水蒸気透過率 が，それぞれ $1 \%$ と10\% になるときの水分吸着率（吸 湿剂単位重量あたりの吸着水量)，扣よび飽和水分吸着 率を温度の関数として示したものである。吸湿剤単位重 量あたりの吸着水分量は，一般にサンプリングする空気 の相対湿度の上昇とともに増加する傾向がある た原子师师室内の温湿度は, 年間を通じてそれぞれ 15〜 $30^{\circ} \mathrm{C}, \quad 30 \sim 90 \%$ の範囲にあるので，排気筒からのサン プリングに括いて，1\% の水蒸気透過率まで使用すると すれば，Fig. 2 から吸湿剤の $15 \%$ 以上の水蒸気を吸 


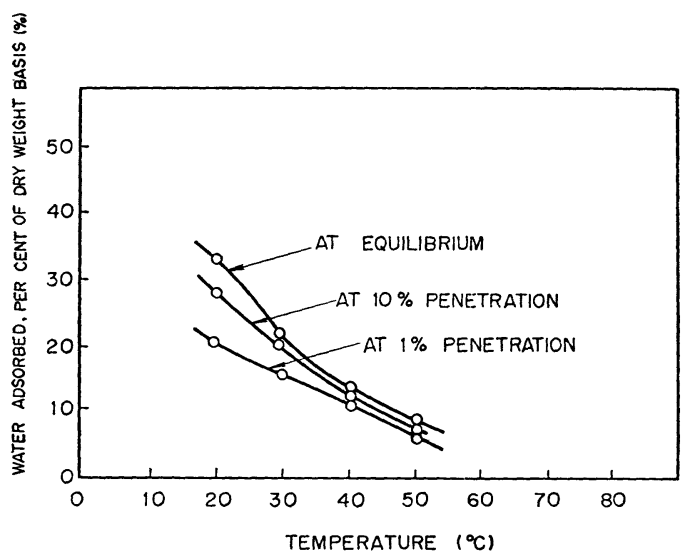

Fig. 2 Weight percentage of the adsorbed water in silica gel at various penetration rates.

Flow rate: $6 \mathrm{l} / \mathrm{min}$, partial pressure of the vapor : $10.5 \mathrm{mmHg}$.

着できることがわかる。

トリチウムを含まない水蒸気を, 水蒸気透過率が高く なるまで十分に吸着させ，ついでトリチウムを含む水蒸 気を流入させたとき，トリチウム透過率（シリカゲルの 出口と入口に括けるトリチウム濃度の比）は, この時点 に拈ける水蒸気透過率より低い值になった。これは, ト リチウム水蒸気がシリカゲルを通過する間に, 吸着され ていた水分と置換するすのと考えられい)，このことから 水蒸気を吸着し, 吸着能力の低下したシリカゲルに, 突 然高濃度のトリチウム水蒸気を含む空気が流入しても, トリチウムは十分シリカゲルに吸着されることがわか った。

\section{III 吸湿シリカゲルからの水採集方法}

シリカゲルからの採水に使用した装置を Fig. 3 亿示 す。水蒸気を吸湿した吸着塔を水蒸気捕集系から取りは ずし, 吸着塔周囲にリボンヒータ $(200 \mathrm{~W})$ をまいて加 熱し, 同時に乾燥した空気を吸着塔の下方から上方に流 通させて, シリカゲルから脱着した水蒸気を冷却器に導

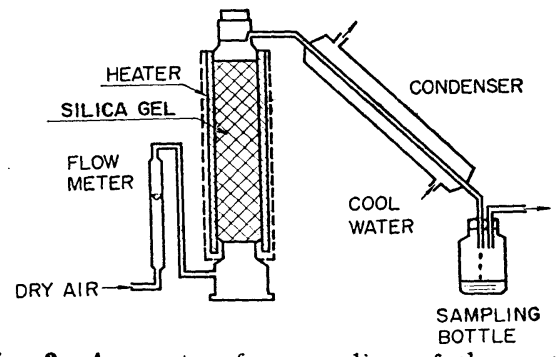

Fig. 3 Apparatus for sampling of the water adsorbed in silica gel.
き，凝集させて水試料を得た。

乾燥した空気の流量率と凝集する水量との関係は, 冷 却水の温度と冷却器の性能に依存するが, 上記の加熱条 件では流量率 $2 \sim 8 \mathrm{l} / \mathrm{min}$ の範囲が効率よく採水でき た。これ以下の流量率では水蒸気が冷却器に流入せず, これ以上では水蒸気の凝集効率が下がる。最初の水滴が 試料ビンに得られるのは, 加熱後 10〜15 分であった。

サンプリングする空気中のトリチウム濃度が時間とと もに変化する場合, 吸湿したシリカゲル中のトリチウム 濃度がシリカゲルの位置（入口からの距離）により異な り，採水されるトリチウム濃度も，加熱開始時間経過と ともに変化することが考えられる。これを調べるため に, 使用量の $1 / 4$ のシリカゲルにトリチウムを含む水蒸 気を吸着させ，これを Fig. 4 に示す位置，すなわち(1) 下方，(2)中間，(3)上方にそれぞれ設置し，他の $3 / 4$ はト リチウムを含まない水蒸気を同重量比だけ吸着させたシ リカゲルを詰めて，水分を採水した。また，これらのシ リカゲルを均一に靦拌した場合についても，水分を脱着 させた。このとき採集される水のトリチウム濃度は，

Fig. 4 のように加熱時間とともに変化することが認めら れた。しかし，㩇找した場合は，どの時点の水試料のト リチウム濃度も同一であった。あらかじめ吸着水分重量 を脱着前に計測し，またシリカゲルを撜抖して採水すれ

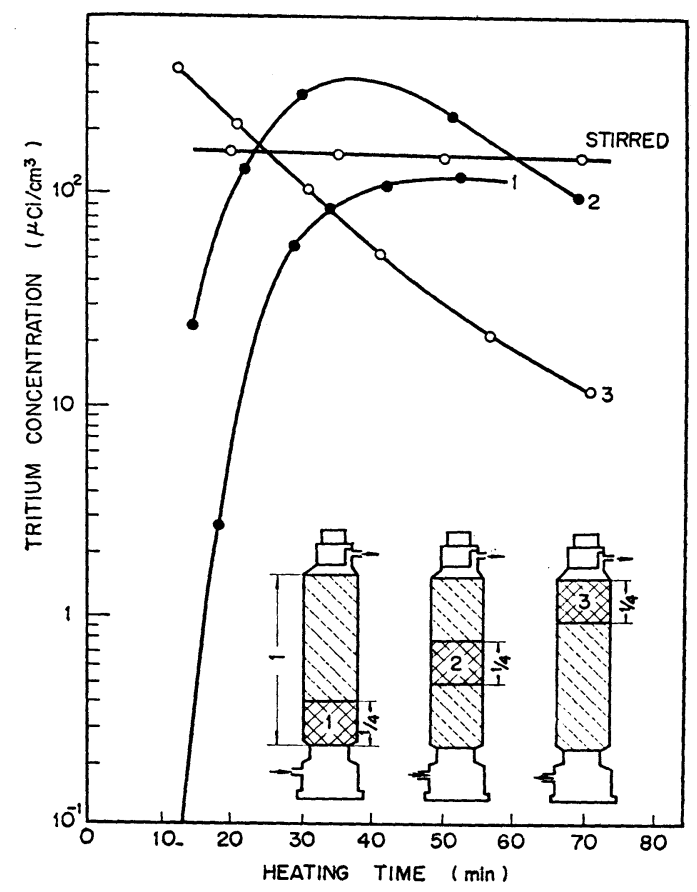

Fig. 4 Variation of the tritium concentration in water samples with heating time. 
ば，吸着している水分を完全に採水しなくても，採水し た最初の 1 滴のトリチウム濃度を測定することにより， 吸着した全トリチウム量が求められることがわかった。

\section{IV 結言}

現在，この方法を用いて原研重水炉の排気筒から排出 されるトリチウムの量を測定しているが，ドライアイス を使用した水蒸気凝集法から求めた值と, 注济一致する ことが認められている。シリタゲルを $370 \mathrm{~g}$ 使用し，流 量率 $100 \sim 200 \mathrm{~cm}^{3} / \mathrm{min}$ で流通させたとき， 1 カ月連続 の排気中トリチウムのサンプリングが可能である。シリ カゲルから吸着水分を採水する場合, シリカゲルを採水 前に挸找して採水すれば，全吸着水分を採水する必要が なく，一部の水を採水することで，吸着含水分量を推定 することができることがわかった。他の核種と混合して 排出される場合，および低濃度のトりチウムが排出され ている場合に，長期間にわたる連続したトリチウムの排 出量を測定するには, 本方法はより簡便, 確実で感度の よい方法である。

本報告をまとめるにあたり，ご指導いただきました日 本原子力研究所, 放射線管理課長, 吉田芳和博士および 同課長代理国分守信氏に感謝します。

\section{参考文 献}

1) R.V. OSBORNE; Studies and techniques in tritium Health Physics at CRNL, Canadian Rep. AECL-2699 (1967).
2) J.H.OSLOOND et al. ; A tritium air sampling method lfor environmental and nuclear plant monitoring, Abstracts for the tritium symposium 34, No. 66 (1971).

3) J.C.DALY et al. ; Tritium moisture in the atmosphere surrounding a nuclear fuel reprocessing plant, Radiological health data and reports, 9, 341 (1968).

4) T.L.THOMAS ; 6 th World petrol. cong. (Frankfurt), Part 3, No. 16 (1963).

5) “Chemical Engineers' Handbook" (3 rd Edition), p. 880(1950), McGrow-Hill Book Co.

6) R.G. AUNE et al. ; LBL-2 (1971).

\section{会費払込のお願い}

当協議会の会費は，前納制になって扣りますので 昭和 47 年度分, 拉よびそれ以前の年度の会費を未 納の方は，至急拈払込みくださいますよう拍願いい たします。

現在，会費の納入を遅滞されている方が大分叔り 事業運営上非常に支障をきたして和ります。都合上 退会される方は，退会手続をとるよう打願いいたし ます。

会費 正会員 1,500 円 準会員 1,000 円

な扮振込口座番号は東京 24488 (払込料金は当協 議会負担）です。 